\title{
Poesías completas de José María Heredia: hacia una tradición futura
}

\author{
Nahum Villamil Garcés \\ Universidad de Cartagena
}

Tilmann Altenberg. Poesías completas de José María Heredia. Edición crítica. Iberoamericana-Vervuert, 2020. 1045 págs.

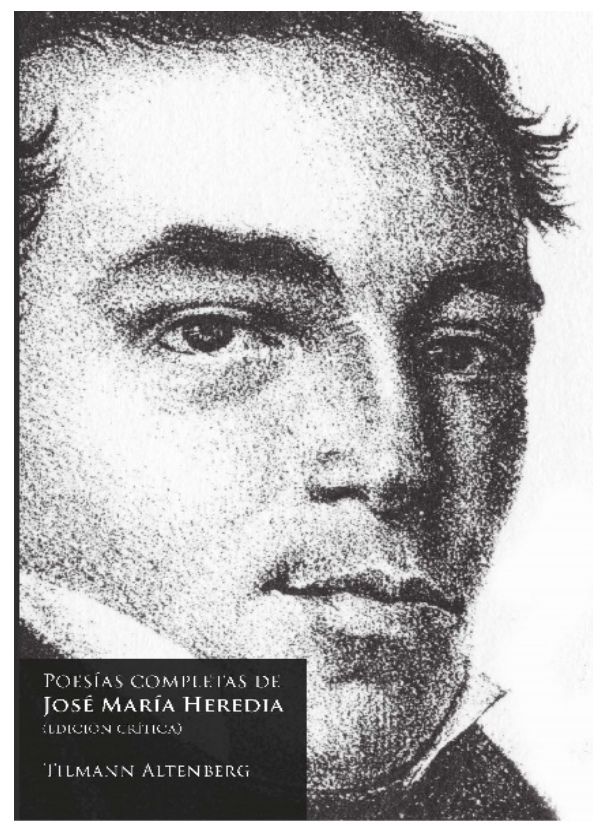

Reunir las obras completas de un autor, si apelamos a palabras de Juan Villoro, es darle coherencia retrospectiva al azar y reponer silencios. El crítico Tilmann Altenberg e IberoamericanaVervuert publican Poesías completas de José María Heredia, trabajo que traza una nueva y bien documentada coherencia para la obra de un poeta mayor de nuestras letras.

La poesía de José María Heredia (Santiago de Cuba, 1803) encuentra en este volumen, al fin, su justa dimensión. En los casi doscientos años transcurridos tras su muerte, la obra del cantor del Niágara ha visto lecturas variadas, numerosas ediciones, entusiasmos conmemorativos y reivindicaciones patrióticas. Ahora bien, estos entusiasmos no han dejado de ocasionar la paradójica malversación de su valor: donde hubo fervor por el centenario, anidó un silencio de décadas; donde hubo efigies, se talló también la miopía del nacionalismo; donde la industria editorial multiplicó su obra, se prolongaron erratas y se tejieron apócrifos.

En este panorama, Altenberg, quien ya había publicado en 2001 el riguroso estudio Melancolía en la poesía de José María Heredia, da cuenta en esta edición, después de quince años de trabajo, de las importantes contradicciones alrededor de la historiografía heredista. Así, mientras el lugar común ha instalado a Cuba como referente primario en la obra de Heredia, Altenberg reivindica el horizonte interpretativo de su vida en México y cómo este permite ir más a fondo en el código biográfico referencial que ofrece la obra del poeta.

Y si bien la lectura de una complementariedad cubano-mexicana es fundante a la hora de pretender una comprensión de los textos de Heredia, el hecho sustancial que distingue a esta nueva publicación radica en la pormenorizada búsqueda de archivo y cotejo con las ediciones anteriores, que le permitió descubrir sus consistentes falencias. Estas varían en diversidad e importancia: algunas desestiman los primeros poemas, aunque, señala Altenberg, "Conviene recordar que la reputación literaria de Heredia emergió, en primera instancia, a partir de poemas manuscritos que circularon entre amigos y conocidos". Otras eluden publicar las traducciones e imitaciones realizadas por Heredia, al mismo tiempo que tampoco se ocupan en ofrecer precisiones cronológicas. Asimismo, se cuentan también aquellas que impusieron arbitrariedades de estilo, como iniciar de forma indiscriminada los versos con mayúsculas o enmiendas injustificadas y transcripciones erróneas. No faltan tampoco las que le atribuyen poesías ajenas y le sustraen su autoría de algunos versos propios. 
Frente a este panorama de ediciones que reclaman el título de completas, Altenberg ofrece en orden cronológico el pleno de la poesía publicada por Heredia (más un testimonio que permanecía inédito), brinda claves que permiten una mayor certeza en la atribución de tres poemas y desestima otra triada cuyos autores quedan ahora establecidos. Tras esta fijación de textos corresponde el desarrollo de un derrotero crítico, conforme a los criterios de una ecdótica moderna. Así, esta edición cuenta con numeración e índice de primeros versos, una nutrida cronología y un sólido aparato crítico que no escatima en ofrecer datos históricos, contrastes de los distintos testimonios de cada poema, luces interpretativas al interior de la propia obra y, entre otros factores que el lector podrá comprobar por sí mismo, proporciona el entramado de notas urdidas por el mismo José María Heredia y aquellas confeccionadas para esta edición y los lectores contemporáneos.

Dos relatos históricos escritos por Alejandro González Acosta forman también parte de este volumen. El primero esclarece algunas nociones sobre la vida de José María Heredia y traza una trayectoria vital muy útil para comprender cómo desarrolló su vasta cultura y así situarlo en "el ideal dieciochesco del hombre sensible en el que se orientan, sin duda, la autopercepción y autorrepresentación del cubano", como sugiere Altenberg en su análisis de la melancolía en la obra de Heredia. Si bien el segundo es breve, pone en relieve la gestación del proyecto, algunos de sus pormenores, testimonia la ambición que supone llevar a cabo un trabajo riguroso y sirve de correlato para futuras aproximaciones a empresas similares que enriquezcan nuestra comprensión de la literatura latinoamericana.

José María Heredia ha sido excusa argumental y personaje de ficciones literarias. Quizás las más reputadas son El mundo alucinante (1969), de Reinaldo Arenas, y La novela de mi vida (2002), de Leonardo Padura. En esta última, un Heredia ficcional escribe: "Entonces quedará solo el olvido, y tal vez la poesía, libre ya de la intensidad de los días y los años, ajena incluso a ese minuto fulgurante en que se hizo carne y sangre de un hombre". La publicación de sus Poesías completas contradice esa hipótesis pare enriquecerla al no petrificar una versión definitiva sino "hacer visible el perfil histórico de la obra poética del cubano-mexicano". Así, los segmentos que conforman esta edición, a saber: "Colecciones manuscritas", "Ediciones en Vida de Heredia", "Poemas no recogidos en colección", "Poemas atribuidos", "Versiones alternativas", "Apéndices" e "Índices" configuran un continuum interpretativo a través del cual se pueden asediar todas las posibilidades semánticas de sus poemas y las metamorfosis que estos sufrieron a lo largo de las distintas revisiones y correcciones, lo que implica, a todas luces un documento invaluable, tanto para lecturas desprevenidas como para futuros estudios de la obra de Heredia.

Todo trabajo de esta índole es deudor de una tradición. Poesías completas de José María Heredia no es una obra ajena esta premisa. Es posible, justamente, gracias a los vaivenes de la historiografía heredista, con sus aciertos e insatisfacciones. En "Nota sobre (hacia) Bernard Shaw", Borges argumentaba "Si me fuera otorgado leer cualquier página actual — esta, por ejemplo— como la leerán en el año 2000 yo sabría cómo será la literatura del año 2000". Libros como este, en cambio, nos permiten saber de antemano cómo será la lectura en las próximas décadas. 